\title{
SIMULATION STUDY OF THE PROCESS OF FRICTION IN THE WORKING ELEMENTS OF A CAR BRAKING SYSTEM AT DIFFERENT DEGREES OF WEAR
}

\author{
Andrzej BORAWSKI \\ *Faculty of Mechanical Engineering, \\ Bialystok University of Technology, ul. Wiejska 45 C, 15-351 Bialystok, Poland \\ a.borawski@pb.edu.pl
}

received 27 January 2018, revised 17 September 2018, accepted 20 September 2018

\begin{abstract}
Among the many elements of a modern vehicle, the braking system is definitely among the most important ones. Health, and, frequently, life, may rest upon the design and reliability of brakes. The most common friction pair used in passenger cars today is a disc which rotates with the road wheel and a cooperating pair of brake pads. The composite material of the pad results in changing tribological properties as the pad wears, which was demonstrated in experimental studies. The change is also facilitated by the harsh operating conditions of brakes (high and rapid temperature changes, water, etc.). This paper looks into how changing tribology reflects on the heating process of disc and pads during braking. And so a simulation study was conducted, as this method makes it possible to measure temperature in any given point and at any time, which is either impossible or extremely difficult in real life conditions. Finite element method analyses were performed for emergency braking events at various initial speeds of the vehicle reflecting the current road speed limits.
\end{abstract}

Key words: Brake Pads, Friction Heating, Brake Simulation, Coefficient of Friction

\section{INTRODUCTION}

The significance of the braking system in any vehicles is enormous. Its main function is reducing the speed of the moving vehicle or stopping it completely. The wellbeing and life of the vehicle's passengers rests upon it, but also of other, accidental participants of road and pedestrian traffic

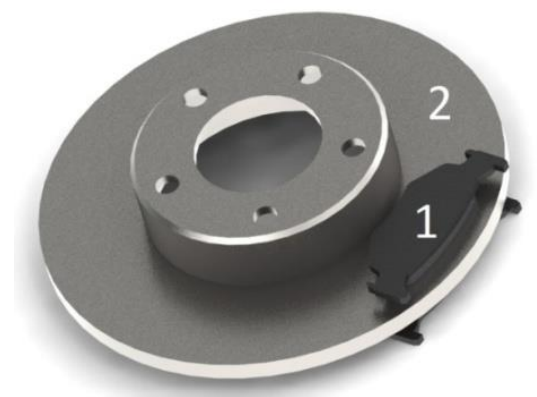

Fig. 1. Brake pad (1) and corresponding brake disc (2) - CAD model developed for the purpose of this paper based on manufacturer data

Most vehicles manufactured today use disc brakes. The main element of this type of design is the disc, spinning alongside the road wheel, and the brake pad, connected with the hub via a caliper (Chandgude and Ganiger, 2016) (Fig. 1). As the pad is pressed against the disc, friction occurs which transforms kinetic energy into heat. The energy, in the form of heat, is then released into the atmosphere (Blauand McLaughlin, 2003). This is a neces- sity, as excess heat may damage the suspension elements, which are made from plastics, or even tires (Kulikowski and Szpica, 2014). Also, there is a lot of strain and stress produced, which can be very destructive (Varinauskaset et al., 2013; Adamowicz, 2016a, 2016b).

The friction force largely depends on the materials used in the production of the friction pair. Brake discs are largely made from gray cast iron, as it is characterised by good thermal conductivity and anti-vibration capacity (Malufet et al., 2007). Matters are different for brake pads. Brake pads manufacturers utilise approximately 2000 different materials (Blau, 2001) which have different effects on the final product. An average brake pad is made from 10 to 20 different substances. Improper composition of a brake pad may lead to the occurrence of fading, causing a significant decrease in the value of the coefficient of friction (even down to zero). This is related to the degradation of resin resulting in the substantial losing of binding properties. That is why the thermal stability of a brake pad, its capacity for maintaining mechanical properties and capacity for binding components under unfavourable conditions of braking may largely depend on the resin (Bijweet et al., 2006). Degradation of some types of resins starts already at $260^{\circ} \mathrm{C}$ (Avalloneet et al., 2007). In order to improve the original mechanical and thermal properties of resins, numerous attempts of modifying their compositions are made (Bijweet et al., 2006; Bijwe, 2007). Multiple instances of heating (to temperatures of up to several hundreds degrees Celsius) and cooling may change the tribological properties of brake pads and discs. Consequently, this may reduce the braking force (Ścieszka, 1998). The corrosive environment brake systems work in (salt and water, especially during winter) are also significant (Borawski, 2016).

Contemporary technological advancement makes it possible 
to use various research techniques in many different ways producing more or less accurate results (Williams, 2010). Also, every method consumes certain costs and time necessary to conduct the tests. Simulations of braking systems or their components are currently a very popular research method (Kamiński, 2013). It is also employed in the study of other components of vehicles (Szpica, 2015a, 2015b) and many technological processes, like welding (Česnavičiuset et al., 2016; Dunduliset et al.,2012; Kilikevičius et et al., 2016). Its popularity stems from low costs in comparison to other tests. In this case, the only requirement is a computer with appropriate software.

Simulations make it possible to obtain information on the heat occurring during braking(Grześ, 2017; Yevtushenkoet et al., 2017). This is a significant benefit of this method as measuring the temperature of a friction pair is difficult, and sometimes impossible, especially in the case of brakes (Borawski, 2018), and that is why the method was chosen for this study. The aim of this paper is to determine whether and how the wear ofa brake system's working elements affects the process of heating of the pad and disc during braking.

\section{STUDY OBJECT AND METHODOLOGY}

The study involved brake pads (and their CAD models) which were both brand new and at various degrees of wear, made available thanks to the courtesy of the Authorised Service Dealer. The structure of one of the studied pads is presented in Fig. 2. The picture very clearly shows the three layers significant for this study: the friction material (1), the adhesive layer (interlayer), and the metal backplate (3).

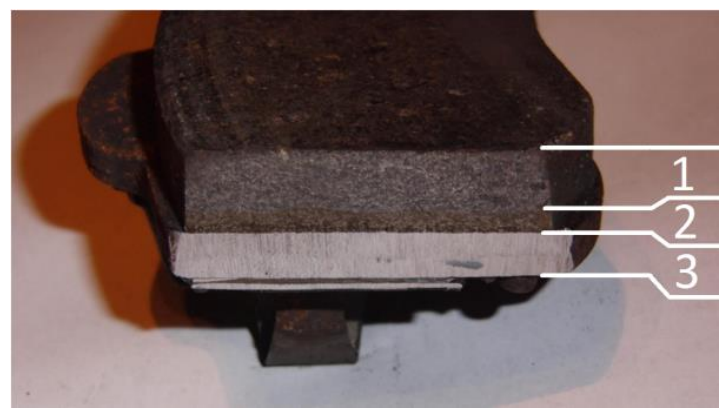

Fig.2. Cross-section of the real-life object of study: 1 - friction material, 2 - adhesive layer (interlayer), 3 - metal backplate

Tab. 1.Selected properties of brake pad layers

\begin{tabular}{|c|c|c|}
\hline \multirow{3}{*}{ 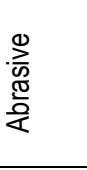 } & Thermal conductivity & $148\left[\mathrm{~W} /\left(\mathrm{m}^{*} \mathrm{k}\right)\right]$ \\
\hline & Density & $2850\left[\mathrm{~kg} / \mathrm{m}^{3}\right]$ \\
\hline & $\begin{array}{l}\text { Heat capacity at } \\
\text { constant pressure }\end{array}$ & $1030\left[\mathrm{~J} /\left(\mathrm{kg}^{*} \mathrm{~K}\right)\right]$ \\
\hline \multirow{3}{*}{ 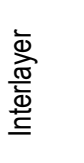 } & Thermal conductivity & $84\left[W /\left(m^{*} k\right)\right]$ \\
\hline & Density & $2248\left[\mathrm{~kg} / \mathrm{m}^{3}\right]$ \\
\hline & $\begin{array}{l}\text { Heat capacity at } \\
\text { constant pressure }\end{array}$ & $1220\left[\mathrm{~J} /\left(\mathrm{kg}^{*} \mathrm{~K}\right)\right]$ \\
\hline \multirow{3}{*}{ 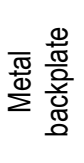 } & Thermal conductivity & $440\left[\mathrm{~W} /\left(\mathrm{m}^{*} \mathrm{k}\right)\right]$ \\
\hline & Density & $7845\left[\mathrm{~kg} / \mathrm{m}^{3}\right]$ \\
\hline & $\begin{array}{l}\text { Heat capacity at } \\
\text { constant pressure }\end{array}$ & $58\left[\mathrm{~J} /\left(\mathrm{kg}^{*} \mathrm{~K}\right)\right]$ \\
\hline
\end{tabular}

Microscopic observation indicated, that the friction material is made of: metal fibers $\sim 15 \%$, organic fiber $\sim 15 \%$, binder (resin) $20 \%$, solid lubricants $\sim 10 \%$, abrasive $\sim 10 \%$, and fillers $\sim 30 \%$. The composition of the interlayer is similar, albeit in different proportions: metal fibers $\sim 10 \%$, organic fiber $\sim 10 \%$, binder (resin) $45 \%$, solid lubricants $\sim 5 \%$, abrasive $\sim 30 \%$, and fillers $\sim 30 \%$. The backplate is made of structural steel. Due to the difference in chemical composition, each of the layers is characterised by distinct properties (Tab. 1).

The discussed brake pad works in tandem with a brake disc made of grey cast iron. The properties of this material as used in the simulation are presented in Tab. 2.

Tab.2.Selected material properties of the brake disc

\begin{tabular}{|c|c|}
\hline Thermal conductivity & $47\left[\mathrm{~W} /\left(\mathrm{m}^{*} \mathrm{k}\right)\right]$ \\
\hline Density & $7870\left[\mathrm{~kg} / \mathrm{m}^{3}\right]$ \\
\hline $\begin{array}{c}\text { Heat capacity at constant } \\
\text { pressure }\end{array}$ & $498\left[\mathrm{~J} /\left(\mathrm{kg}^{*} \mathrm{~K}\right)\right]$ \\
\hline
\end{tabular}

The coefficient of friction of the pad/disc pair was determined by laboratory tests (Yevtushenko and Borawski, 2018). The results clearly indicate that the coefficient changes as the brake pad wears down (Tab. 3).

Tab.3.Coefficient of friction test results (Yevtushenko and Borawski, 2018)

\begin{tabular}{|c|c|c|}
\hline $\begin{array}{c}\text { Brake pad wear } \\
{[\%]}\end{array}$ & $\begin{array}{c}\text { Average value of the } \\
\text { coefficient of friction }\end{array}$ & $\begin{array}{c}\text { Standard } \\
\text { deviation }\end{array}$ \\
\hline 0 & 0.45 & \pm 0.045 \\
\hline$\sim 10$ & 0.46 & \pm 0.022 \\
\hline$\sim 25$ & 0.43 & \pm 0.031 \\
\hline$\sim 40$ & 0.4 & \pm 0.014 \\
\hline$\sim 45$ & 0.41 & \pm 0.016 \\
\hline$\sim 50$ & 0.39 & \pm 0.031 \\
\hline$\sim 60$ & 0.36 & \pm 0.021 \\
\hline$\sim 70$ & 0.37 & \pm 0.024 \\
\hline$\sim 80$ & 0.35 & \pm 0.052 \\
\hline$\sim 90$ & 0.6 & \pm 0.037 \\
\hline 100 & 0.85 & \pm 0.049 \\
\hline
\end{tabular}

The friction pair comes from a passenger car whose total weight is $1550 \mathrm{~kg}$. The vehicle is furnished with 205/55/R16 tires. Based on the diameter of the tires, the dynamic radius used in the study equals $251 \mathrm{~mm}$. It was assumed that braking occurs without slippage, and the coefficient of adhesion is 1.0. This leads to a deceleration of $9.81 \mathrm{~m} / \mathrm{s}^{2}$. Also, the assumed ambient temperature is $25^{\circ} \mathrm{C}$. The initial speed of the car was $50 \mathrm{~km} / \mathrm{h}, 90 \mathrm{~km} / \mathrm{h}$, and $140 \mathrm{~km} / \mathrm{h}$, as these are the most common speed limits in urban and non-urban areas, and motorways. The study analysed the first 10 seconds from the initiation of braking. The step was $0.05 \mathrm{~s}$.

Moreover, the following assumptions were made:

- unchanging coefficients of friction;

- stable and homogeneous contact pressure for both pads;

- homogeneous brake pad material and full surface contact,

- constant braking deceleration;

- no external factors (such as road inconsistencies, air resistance). 


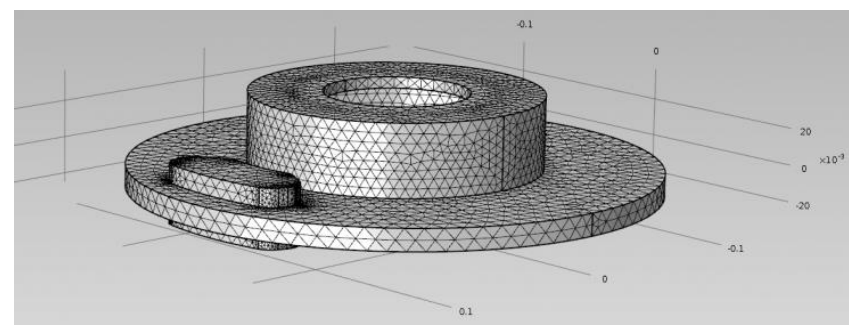

Fig.3. Final geometry of analyzed disc and pads

The simulations were conducted using FEM in Comsol Multiphysics 4.4. In order to avoid unnecessary mesh density, the CAD models were simplified by removing those elements which do have no significant influence on the end result (such as the brake disc slots or the elements which position the pad in the clamp). The final mesh comprised approximately 6200 mostly triangular elements, providing close to 32000 degrees of freedom. Final geometry of analyzed disc and pads is shown in Fig. 3.

The force of the braking process can be describes as a negative derivative of the vehicle's kinetic energy (Yevtushenko and Grzes, 2015):

$P=-\frac{d}{d t}\left(\frac{m v^{2}}{2}\right)$

or

$P=-m R^{2} \omega(t) \alpha$

where: $\mathrm{m}$ - vehicle's mass, $\mathrm{v}$ - speed of the vehicle, $R$-dynamic radius of the road wheel, $\omega$ - angular velocity of the wheel, $t$ - time, $\alpha$ - angular deceleration.

Assuming that the braking deceleration is constant, we may say that

$\omega(t)=\omega_{0}+\alpha t(3)$

A simple stability analysis of the vehicle made demonstrated that approximately $60 \%$ of the total braking force comes from the front wheels (roughly $15 \%$ per each of the four brake pads on the front axis). It has been assumed that each of the brake pads generates identical braking force. The relation between the braking force of one wheel and the complete vehicle is as follows:

$F_{b}=\frac{100 \% \cdot F_{f b}}{2 \cdot 15 \%} \approx 3.33 \cdot F_{f b}$

where: $F_{f b}$ - braking force generated by one front wheel, $F_{b}-$ total braking force of the vehicle.

On that basis, the braking force of the vehicle can be described as (Richardson and Coulson, 1999)

$P=-3.33 \iint f_{f} \cdot d A \cdot v_{d}$

where: $f_{f}$ - frictional force per surface unit, $v_{d}=\omega(t) \cdot r$ - brake disc linear speed at radius $r, A$ - disc and pad contact surface area.

The braking force is also expressed as the relation (Richardson and Coulson, 1999)

$P=f_{f}(t) \cdot \omega(t) \iint r_{m} \cdot d A$

where $r_{m}$ - distance from the pad's centre of mass to the disc rotation axis.

Comparison of the two equations makes it possible to determine the $f_{f}$ coefficient: $f_{f}=-\frac{m R^{2} \alpha}{3.33 r_{m} A}$

Assuming that the vehicle's deceleration occurs only through the action of the brake disc and pad, the heat flux can be expressed using the equation (Talati and Jalalifar, 2009)

$q(r, t)=-f_{f} \cdot v_{d}(r, t)$

or

$q(r, t)=-\frac{m R^{2} \alpha}{3.33 r_{m} A} r\left(\omega_{0}+\alpha t\right)$

Amonton-Coulomb friction law (Yanet et al., 2002) makes it possible to determine the contact pressure, which in the analysed case is as follows:

$p=\frac{P}{\mu \cdot v}$

where: $\mu$ - coefficient of friction between the disc and pad.

Also, the study takes into account the heat exchange occurring between the disc and pad, expressed as the following relation (Carey, et et al., 2008)

$\rho \cdot C_{p} \frac{\partial T}{\partial t}+\nabla \cdot(-k \cdot \nabla T)=Q-\rho \cdot C_{p} \cdot u \cdot \nabla T$

where: $k$ - thermal conductivity, $C_{p}$ - thermal capacity, $u$ - heat flux rate, $Q$ - heating power per density unit, $\rho$ - density, $T$ - temperature.

During the action of the brakes, the following amount of heat is released through convection and radiation (Richardson and Coulson, 1999)

$q_{d}=-h\left(T-T_{r}\right)-\varepsilon \sigma\left(T^{4}-T_{r}{ }^{4}\right)$

where: $h$ - convection coefficient, $\left(T-T_{r}\right)$ - temperature difference between the friction material and ambient temperature, $\varepsilon-$ emissivity of material, $\sigma$ - Stefan-Boltzman constant.

The relation between the convection coefficient and the speed of the vehicle is described as follows (Richardson and Coulson, 1999):

$h=\frac{0.037 k}{l}\left(\frac{\rho \cdot l \cdot v}{\mu}\right)^{0.8} \cdot\left(\frac{C_{p} \cdot \mu}{k}\right)^{0.33}$

where: $l$ - disc diameter, $\mu$ - viscosity.

\section{RESULTS AND DISCUSSION}

The most important value measured in the study was temperature. It was gauged in two points: in the geometrical centre of the braking pad at $0.2 \mathrm{~mm}$ from its surface (Figs. 4-6) and at $0.2 \mathrm{~mm}$ from the surface of the disc at the opposite side, i.e. after turning it by $180^{\circ}$ (Figs.7-9).

The graphs show that the difference between maximum temperatures for all test conditions is slight, no more than 20 degrees. The highest temperature reached by the friction pair occurs when the disc cooperates with a completely worn pad (see curve no. 11 in Figs. 4-9). The analysis of the above graphs indicates that there is heat exchange after stopping the vehicle, as a result of various properties of the cooperating materials. Due to convection, the brake pad takes part of the energy accumulated in the disc, as demonstrated by a temporary increase in the pad's temperature. Next, the friction elements are gradually cooling through radiation. Yet the phenomenon does not occur in the case of a fully worn brake pad. This is the result of the similar properties of the brake disc and pad backplate materials. 

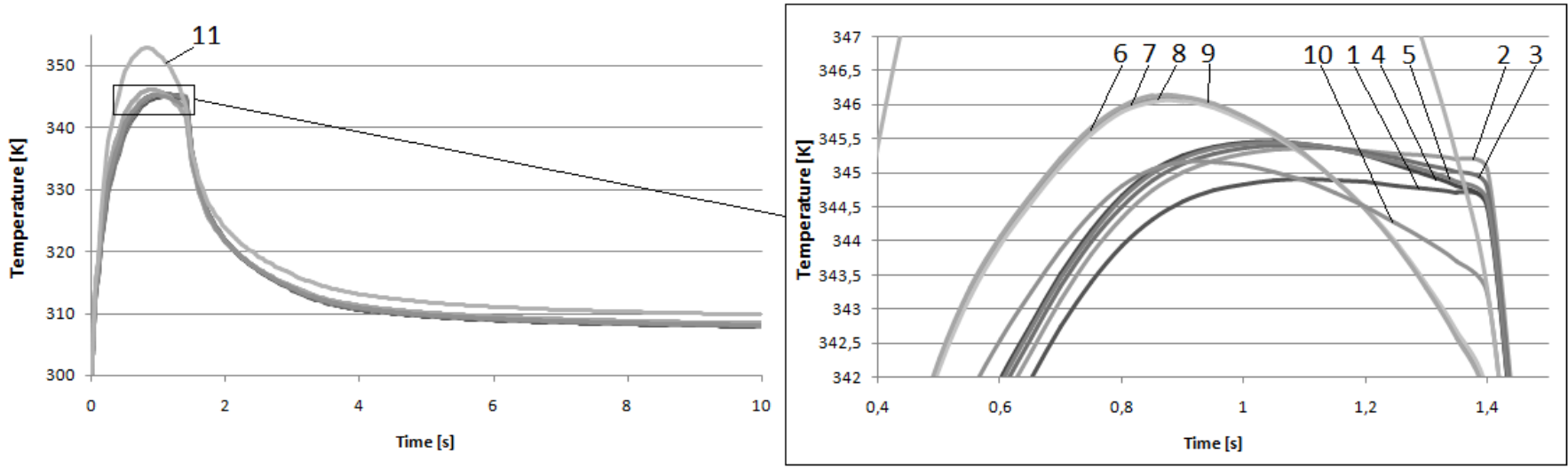

Fig.4. Brake pad temperature change during emergency braking commencing at initial speed of $50 \mathrm{~km} / \mathrm{h}$ : 1 - brand new brake pad, 2 - brake pad wear at approx. 10\%, 3-brake pad wear at approx. 25\%, 4-brake pad wear at approx. 40\%, 5-brake pad wear at approx. 45\%, 6-brake pad wear at approx. 50\%, 7 - brake pad wear at approx. 60\%, 8 - brake pad wear at approx. 70\%, 9 - brake pad wear at approx. $80 \%, 10-$ brake pad wear at approx. $90 \%, 11$ - brake pad wear at $100 \%$
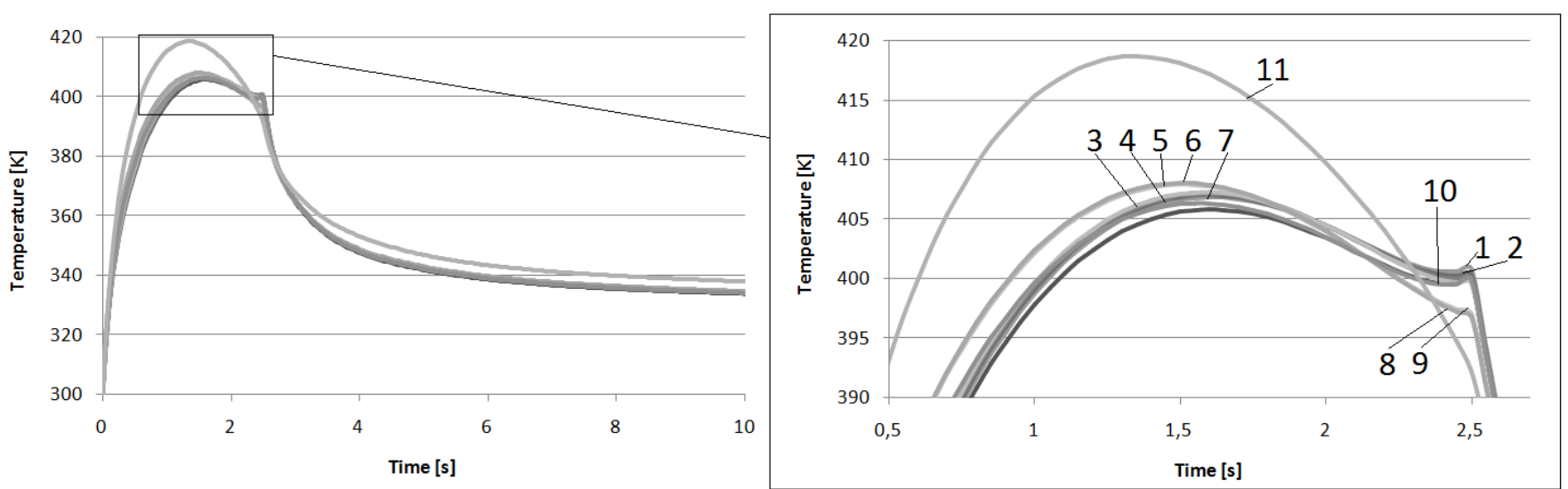

Fig.5. Brake pad temperature change during emergency braking commencing at initial speed of $90 \mathrm{~km} / \mathrm{h}: 1$ - brand new brake pad, 2 - brake pad wear at approx. 10\%,3-brake pad wear at approx. 25\%, 4-brake pad wear at approx. 40\%, 5-brake pad wear at approx. 45\%, 6 - brake pad wear at approx. 50\%, 7 - brake pad wear at approx. $60 \%, 8$ - brake pad wear at approx. 70\%, 9 - brake pad wear at approx. $80 \%, 10$ - brake pad wear at approx. $90 \%, 11$ - brake pad wear at $100 \%$
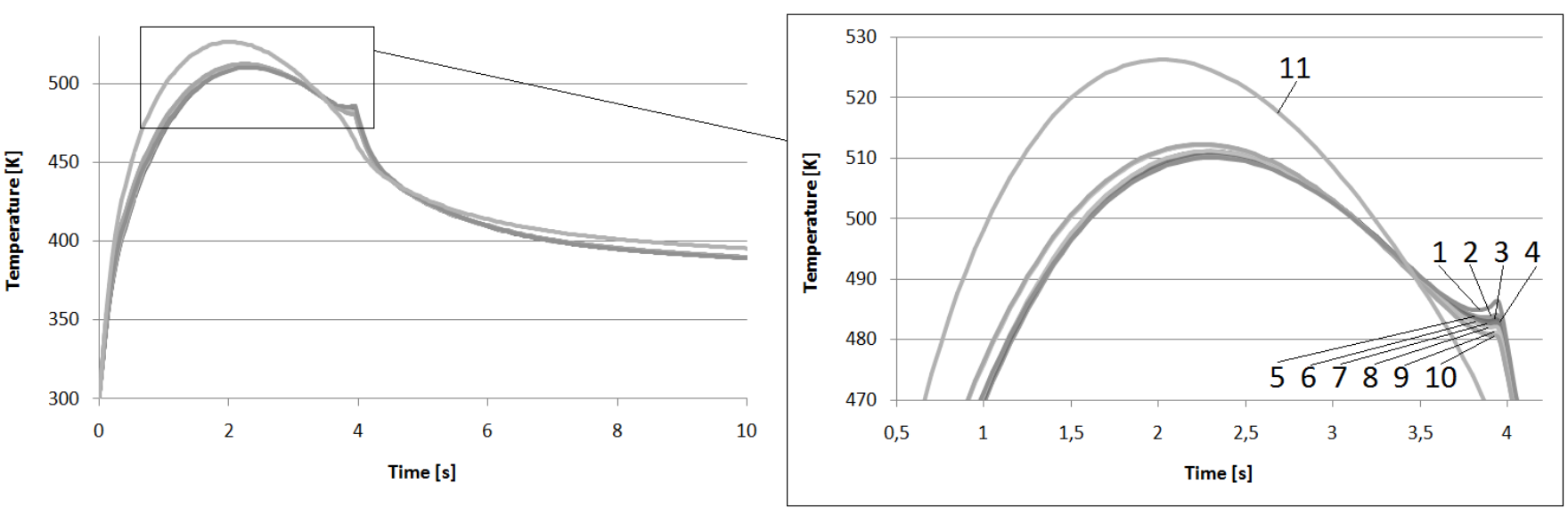

Fig.6.Brake pad temperature change during emergency braking commencing at initial speed of $140 \mathrm{~km} / \mathrm{h}: 1$ - brand new brake pad, 2 - brake pad wear at approx. 10\%,3-brake pad wear at approx. 25\%,4-brake pad wear at approx. 40\%, 5 - brake pad wear at approx. 45\%, 6 - brake pad wear at approx. 50\%, 7 - brake pad wear at approx. 60\%, 8- brake pad wear at approx. 70\%, 9 - brake pad wear at approx. $80 \%, 10$ - brake pad wear at approx. 90\%, 11 - brake pad wear at $100 \%$ 

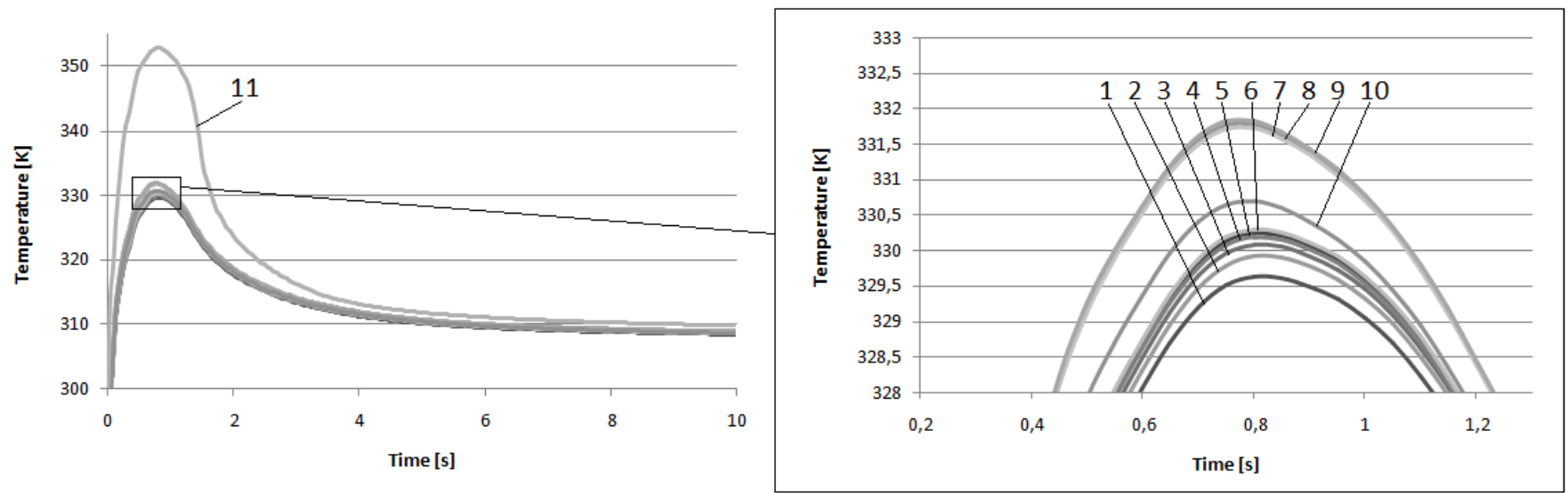

Fig.7. Brake disc temperature change during emergency braking commencing at initial speed of $50 \mathrm{~km} / \mathrm{h}: 1$ - brand new brake pad, 2 - brake pad wear at approx. 10\%, 3 - brake pad wear at approx. 25\%, 4-brake pad wear at approx. 40\%, 5 - brake pad wear at approx. 45\%, 6 - brake pad wear at approx. 50\%, 7 - brake pad wear at approx. $60 \%, 8$ - brake pad wear at approx. $70 \%, 9$ - brake pad wear at approx. $80 \%, 10$ - brake pad wear at approx. 90\%, 11 - brake pad wear at 100\%
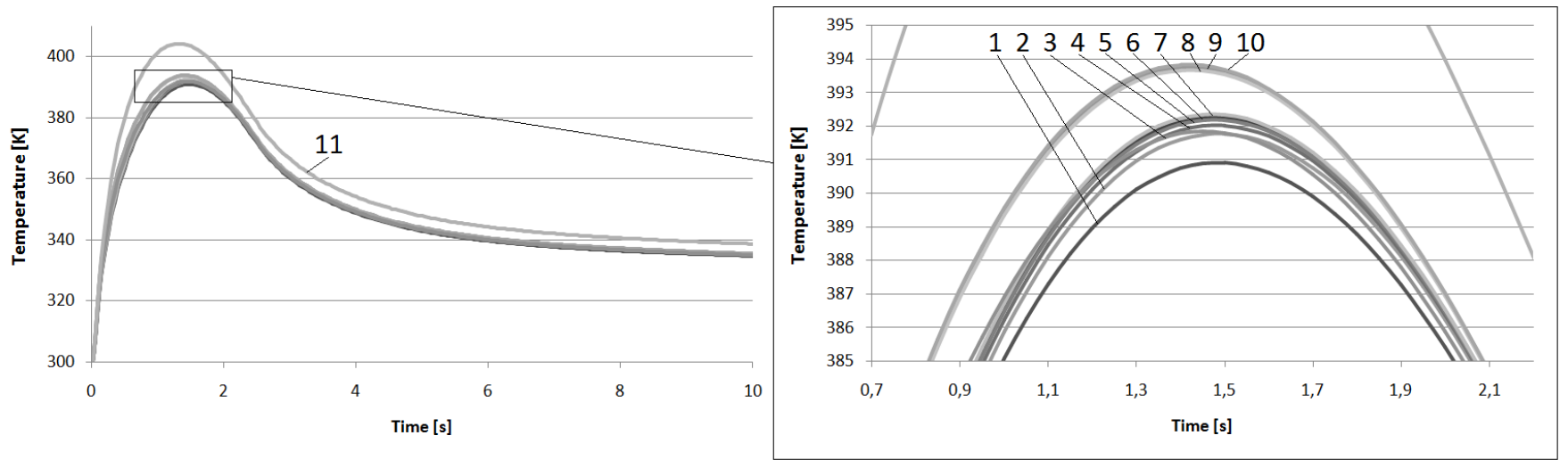

Fig.8. Brake disc temperature change during emergency braking commencing at initial speed of $90 \mathrm{~km} / \mathrm{h}: 1$ - brand new brake pad, 2 - brake pad wear at approx. 10\%, 3-brake pad wear at approx. 25\%, 4-brake pad wear at approx. 40\%, 5-brake pad wear at approx. 45\%, 6 - brake pad wear at approx. 50\%, 7 - brake pad wear at approx. $60 \%, 8$ - brake pad wear at approx. $70 \%, 9$ - brake pad wear at approx. $80 \%, 10$ - brake pad wear at approx. $90 \%, 11$ - brake pad wear at $100 \%$
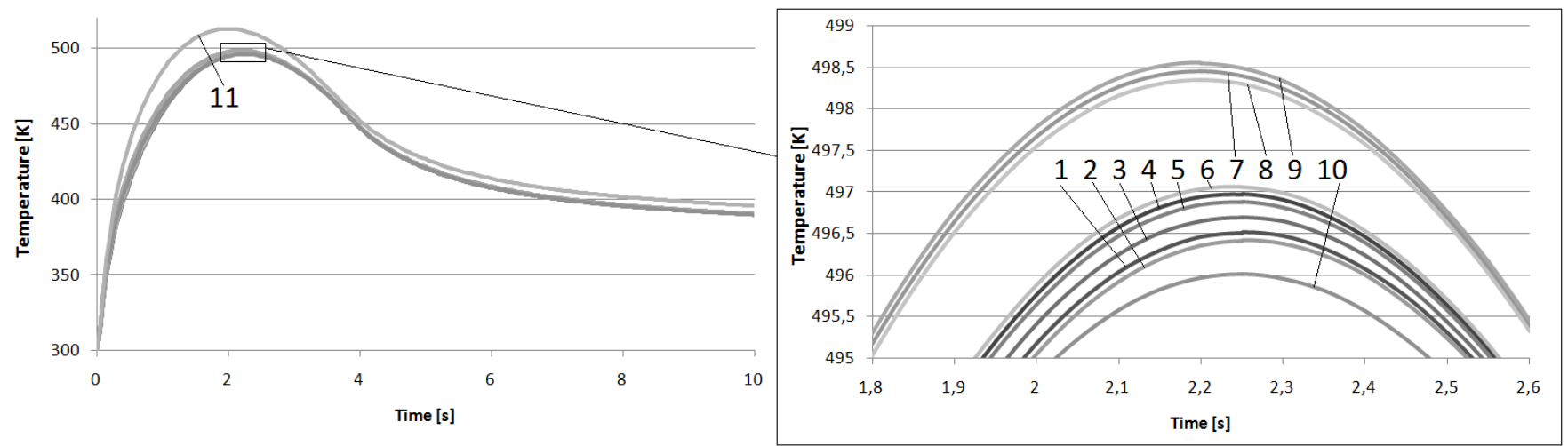

Fig.9. Brake disc temperature change during emergency braking commencing at initial speed of $140 \mathrm{~km} / \mathrm{h}$ : 1 - brand new brake pad, 2 - brake pad wear at approx. 10\%, 3 - brake pad wear at approx. 25\%, 4 - brake pad wear at approx. 40\%, 5- brake pad wear at approx. 45\%, 6 - brake pad wear at approx. 50\%, 7 - brake pad wear at approx. 60\%, 8 - brake pad wear at approx. $70 \%, 9$ - brake pad wear at approx. $80 \%, 10$ - brake pad wear at approx. $90 \%, 11$ - brake pad wear at $100 \%$

Also, the study looked into the amount of heat generated in the analysed cases (Fig.10). Here it can be observed that the wear of the brake pad has no significant impact. The difference for various degrees of wear did not exceed $1 \%$. 


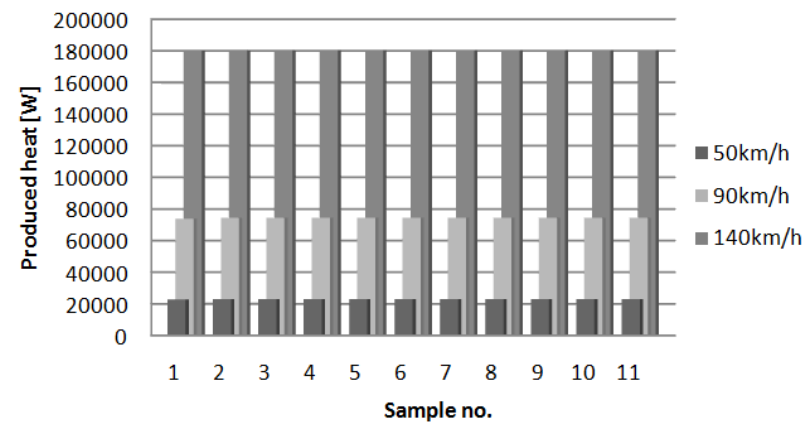

Fig.10. Heat generated by the braking system of one wheel during a vehicle's emergency braking: 1 - brand new brake pad, 2 - brake pad wear at approx. 10\%, 3 - brake pad wear at approx. 25\%, 4 - brake pad wear at approx. $40 \%, 5$ - brake pad wear at approx. 45\%, 6 - brake pad wear at approx. 50\%, 7 - brake pad wear at approx. $60 \%, 8$ - brake pad wear at approx. $70 \%, 9$ - brake pad wear at approx. $80 \%, 10$ - brake pad wear at approx. 90\%, 11 - brake pad wear at $100 \%$

\section{CONCLUSIONS}

This paper presents a comparative simulation of a friction pair comprising in a brake disc and brake pad at various degrees of wear. Due to the nature of the braking process there is risk of "brake fading" which may significantly inhibit brake performance. The results of numerical analyses indicated that:

1. Emergency braking from initial speed of $140 \mathrm{~km} / \mathrm{h}$ bears the risk of brake fading at any degree of brake pad wear.

2. The wear of the brake pad has no significant effect on the maximum temperature achieved by the working elements of the braking system during braking.

3. The wear of the brake pad has no significant effect on the amount of heat generated during braking.

4. The friction pair reaches highest temperature when the brake pad is fully worn (i.e. when the pad's backplate rubs against the disc).

\section{REFERENCES}

1. Adamowicz A. (2016a), Finite element analysis of the $3 D$ thermal stress state in a brake disk, Journal of Theoretical and Applied Mechanics, 54(1), 205-218.

2. Adamowicz A. (2016b), Thermal stressed state of a disk in the process of multiple braking, Materials Science, 51(6), 814-820.

3. Avallone E.A., Baumeister T., Sadegh A.M. (2007), Marks Handbook for Mechanical Engineers, McGraw-Hill, New York.

4. Bijwe J., Nidhi N., Satapathy B.K. (2006), Influence of amount of resin on fade and recovery behavior of non- asbestos organic (NAO) friction material, Tribology Letters, 23(3), 215-222.

5. Bijwe N.J. (2007), NBR-modified resin in fade and recovery module in nonasbestos organic (NAO) friction materials. Tribology Letters, 27, 189-196.

6. Blau P.J. (2001), Compositions, functions and testing of friction brake materials and their additives, Oak Ridge national laboratory report, US Department of Energy (no. 19), Tenessee.

7. Blau P.J., McLaughlin J.C. (2003), Effect of water films and sliding speed on the frictional behavior of truck disc brake materials, Tribology International, 36, 709-715.

8. Borawski A. (2016), Suggested research method for testing selected tribological properties of friction components in vehicle braking systems, Acta Mechanica et Automatica,10(3), 223-226.

9. Borawski A. (2018), Simulation studies of passenger car brake system elements heating process under various braking parameters,
Proceedings of 23nd International Conference MECHANIKA-2018, 58-61.

10. Carey V.P., Chen G., Grigoropoulos C., Kaviany M., Majumdar A. (2008), A review of heat transfer physics, Nanoscale and Microscale Thermophysical Engineering, 12(1), 1-60.

11. Česnavičius R., Kilikevičius S., Krasauskas P., Dundulis R.,

Olišauska H. (2016), Research of the friction stir welding process of aluminium alloys, Mechanika, 22(4), 291-296.

12. Chandgude S.B., Ganiger S.G. (2016), Review on development of composite material for disc brake pad, Journal of Emerging Technologies and Innovative Research, 3(5), 63-65.

13. Dundulis R., Krasauskas P., Kilikevičius S. (2012), Modelling and simulation of strength and damping of the support pillar welded by longitudinal weld, Mechanika,18(2), 135-140.

14. Grzes P. (2017), Determination of the maximum temperature at single braking from the FE solution of heat dynamics of friction and wear system of equations, Numerical Heat Transfer. Part A-Applications, 71(7), 737-753.

15. Kamiński Z. (2013), Experimental and numerical studies of mechanical subsystem for simulation of agricultural trailer air braking systems, International Journal of Heavy Vehicle Systems, 20(4), 289-311.

16. Kilikevičius S., Česnavičius R., Krasauskas P., Dundulis R., Jaloveckas J. (2016), Experimental investigation and numerical simulation of the friction stir spot welding process, Mechanika, 22(1), 59-64.

17. Kulikowski K., Szpica D. (2014). Determination of directional stiffnesses of vehicels'tires under a static load operation, Maintenance and Reliability, 16(1), 66-72.

18. Maluf O., Angeloni M., Milan M.T., Spinelli D., Waldek W., Bose F. (2007), Development of materials for automotive disc brakes, Minerva, 4(2), 149-158.

19. Richardson J.M., Coulson J.F. (1999), Chemical Engineering Vol. 1: Fluid Flow, Heat Transfer and Mass Transfer, The Bath Press.

20. Ścieszka S. F. (1998), Friction brakes - material, structural and tribological problems, ITE, Radom.

21. Szpica D. (2015a), Fuel dosage irregularity of LPG pulse vapor injectors at different stages of wear, Mechanika, 22(1), 44-50.

22. Szpica D. (2015b), Simplified numerical simulation as the base for throttle flow characteristics designation, Mechanika, 21(2), 129-133.

23. Talati F., Jalalifar S. (2009), Analysis of heat conduction in a disk brake system, Heat Mass Transfer, 45, 1047-1059.

24. Varinauskas V., Diliūnas S., Kubilius M., Kubilius R. (2013), Influence of cantilever length on stress distribution in fixation screws of All - on - 4 full - arch bridge, Mechanika, 19(3), 260-263.

25. Walliman N. (2010), Research Methods: The Basics, Routledge, London.

26. Yan W., O'Dowd N.P., Busso E.P. (2002), Numerical study of sliding wear caused by a loaded pin on a rotating disc, Journal of the Mechanics and Physics of Solids, 50, 449-470.

27. Yevtushenko A.A., Borawski A. (2018), Influence of exploitation period on selected tribological properties of brake pads (in Russian), Journal of Friction and Wear, in print.

28. Yevtushenko A.A., Grzes P. (2015), 3D FE model of frictional heating andwearwith a mutual influence of the sliding velocity and temperature in a disc brake, International Communications in Heat and Mass Transfer, 62, 37-44.

29. Yevtushenko A.A., Kuciej M., Grzes P., Wasilewski P. (2017), Temperature in the railway disc brake at a repetetive short-term mode of braking, International Communications in Heat and Mass Transfer, $84,102-109$

Acknowledgements: The research has been carried out within work no. S/WM/2/2013 accomplished at Bialystok University of Technology and financed from the funding allocated for science by the Ministry of Science and Higher Education of Poland and research project no. MB/WM/4/2017, financed from funds used for the development of young scientists and doctoral students. 